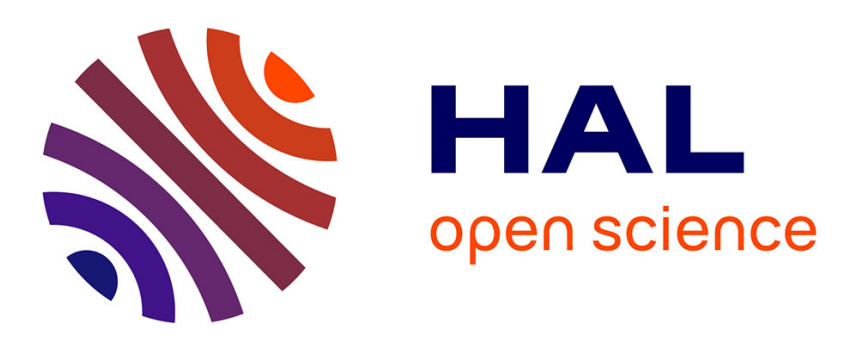

\title{
Erratum : Nature of the mesophase of a conducting charge transfer complex: neither discotic nor calamitic
}

\author{
P. Davidson, A.M. Levelut, H. Strzelecka, V. Gionis
}

\section{To cite this version:}

P. Davidson, A.M. Levelut, H. Strzelecka, V. Gionis. Erratum: Nature of the mesophase of a conducting charge transfer complex: neither discotic nor calamitic. Journal de Physique Lettres, 1983, 44 (24), pp.1039-1039. 10.1051/jphyslet:0198300440240103900 . jpa-00232295

\section{HAL Id: jpa-00232295 https://hal.science/jpa-00232295}

Submitted on 1 Jan 1983

HAL is a multi-disciplinary open access archive for the deposit and dissemination of scientific research documents, whether they are published or not. The documents may come from teaching and research institutions in France or abroad, or from public or private research centers.
L'archive ouverte pluridisciplinaire HAL, est destinée au dépôt et à la diffusion de documents scientifiques de niveau recherche, publiés ou non, émanant des établissements d'enseignement et de recherche français ou étrangers, des laboratoires publics ou privés. 


\section{ERRATUM}

\section{Nature of the mesophase of a conducting charge transfer complex : neither discotic nor calamitic}

P. Davidson, A. M. Levelut

H. Strzelecka and V. Gionis

(J. Physique Lett. 44 (1983) L-823)

The correct version of figures 1 and 2, p. L-824 is following :<smiles></smiles>

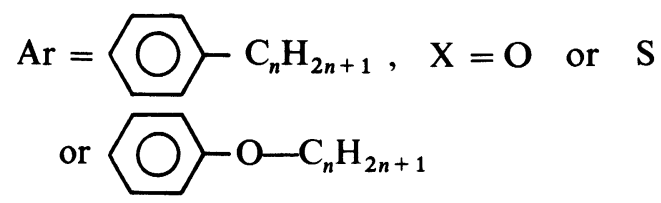

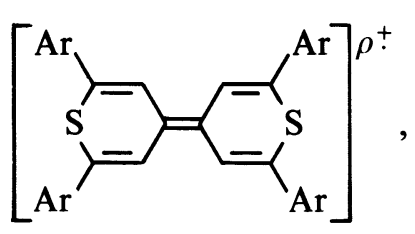<smiles>N#CC(C#N)=c1ccc(=C(C#N)C#N)cc1</smiles><smiles></smiles>

(2) 